\title{
A REPORT ON A FACULTY DEVELOPMENT WORKSHOP FOR ENGINEERING EDUCATORS
}

\author{
McCahan, S; *Stubley, G \\ Department of Mechanical \& Industrial Engineering, University of Toronto, Ontario Canada \\ mccahan@mie.utoronto.ca
}

\section{INTRODUCTION}

In May 2009 we ran a three-day workshop for engineering educators entitled "Engineering a Successful Teaching Experience". This workshop was motivated by a perceived need for a substantial faculty development program that catered to engineering instructors in Canada. Preliminary investigation had suggested that engineering schools in Ontario had enough potentially interested faculty members to make a workshop feasible.

There are similar programs available in the U.S. some of which are open to Canadian faculty (e.g. the National Effective Teaching Institute $^{1}$ ). However, few Canadian faculty participate in these workshops. Some institutions have general faculty development programs available through their teaching and learning centres which engineering instructors utilize. However, it is generally not possible to find enough participants at any one institution to justify running a multiday engineering teaching workshop, and there is currently no national engineering and science teaching development program analogous to the NSF programs in the U.S. For these reasons we decided to initiate this project.

\section{PLANNING}

From previous experience we knew it was essential to determine viability before committing to the project. Therfore, in the fall of 2008 we asked the Deans to commit to purchasing a minimum number of registrations so we could assess the financial viablity of the workshop. We were able to secure advance commitments for 33 participants. In the end, we had 45 registered participants from 10 different Ontario institutions. The participants were generally junior faculty. The workshop was held at the University of Toronto, May 27 to $29^{\text {th }} 2009$.

We based the design of the workshop on faculty development programs we had participated in, or taught, at the University of Waterloo and the University of Toronto. However, we combined various elements of these program with our experience in engineering teaching to create a unique program. The workshop was designed to involve the participants in learning on several levels.

The workshop included interactive lectures, to model effective lecturing. While lecturing may not be as effective as other instructional modes, it is still a very commonly used instructional method in engineering. We decided that it was important to acknowledge this fact and demonstrate ways of making this method more successful.

Because time is a valuable commodity, especially for junior faculty members, we wanted to make sure that participants left the workshop with a tangible piece of work in progress or completed. Work sessions were included which allowed participants to develop or redevelop planning material for a course they were going to teach.

\section{PROGRAM}

Table 1 shows a brief outline of the workshop program. The morning sessions were taught lecture style with a variety of interactive activities interjected. This gave the participants an opportunity to experience lecturing, and the interactive elements, from the student perspective. We conducted debriefs periodically to give the participants an opportunity to reflect on and discuss the instructional methods: what steps the instructor followed; how the method worked; what were the outcomes; etc. This led to discussions about what is and is not effective, and what the challenges are when using interactive methods. In the afternoon of day- 1 and day- 2 of the workshop participants worked on a project: developing or redeveloping a course that they were planning to teach. They worked individually and then presented each element of their course (learning objectives, conceptualization, etc.) to a small group of other participants to get feedback. Feedback and advice was also provided by the workshop facilitators. On the last afternoon of the workshop the participants created posters showing the elements of their course. The workshop ended with a poster session where everyone could walk around and see all the interesting course conceptualizations that had been developed.
Table 1. A brief workshop program outline

\begin{tabular}{|l|}
\hline Day 1 - Situating your course \\
\hline Lectures: \\
- Introduction to course design, situational factors, and learning \\
objectives \\
- Diversity of learners \\
Debrief on instructional methods \\
Small group work: developing learning objectives and identifying \\
$\quad$ situational factors \\
Dinner discussion: TPI and development of a teaching philosophy \\
\hline Day 2 - Organizing your course \\
\hline Lectures: \\
- Course organization concepts \\
Debrief on instructional methods \\
Small group work: developing a graphical course organization \\
Dinner discussion: developing a portfolio to ground your philosophy \\
\hline Day 3 -- Assessment planning and instructional methods \\
\hline Lectures: \\
- Introduction to assessment and feedback \\
Brainstorming and work session \\
Poster session and end of workshop celebration \\
\hline
\end{tabular}

\section{RESULTS}

As shown in Table 2 the workshop evaluations were very positive. In addition, $100 \%$ of the participants who completed the evaluation reported that they would recommend this workshop to a colleague.

Table 2. Relevant results from the workshop evaluation.

\begin{tabular}{|l|l|}
\hline The morning lectures contributed to my learning experience & $95 \%$ \\
\hline $\begin{array}{l}\text { The afternoon tutorials were used effectively to enhance the } \\
\text { topics taught }\end{array}$ & $84 \%$ \\
\hline The course fulfilled its stated aims/objectives & $98 \%$ \\
\hline The content was linked to "real world" experiences & $89 \%$ \\
\hline $\begin{array}{l}\text { The knowledge I have gained through this course will be } \\
\text { useful to me in my career }\end{array}$ & $95 \%$ \\
\hline
\end{tabular}

\section{DISCUSSION}

The workshop was very successful. We had more participants than initially projected It appears that there is a need for this type of event. The evaluations from the participants were very positive, suggesting that the content and delivery was appropriate and useful for this audience.

As we place increasing demands on engineering educators to be excellent at both teaching and research, and as we seek to bring more young talented students into the profession of engineering, workshops as described above can contribute to our efforts to improve the quality and effectiveness of Canadian engineering teaching.

\section{ACKNOWLEDGMENT}

We would like to acknowledge the contributions of Jason Foster and Lisa Romkey (Univ. of Toronto) who served as facilitators during the work sessions and Tricia Cadieux who provided administrative support.

\section{REFERENCES}

1. NETI is 3-day workshop that occurs just before the ASEE annual meeting:

http://www4.ncsu.edu/unity/lockers/users/f/felder/public/NETI.html

\section{AFFILIATED INSTITUTIONS FOR CO-AUTHORS}

*Department of Mechanical \& Mechatronics Engineering, University of Waterloo, Ontario Canada 